\section{COMPARING LEGISLATURES IN MOLDOVA AND MACEDONIA}

William Crowther, University of North Carolina, Greensboro, USA

DOI: $10.1017 / S_{1049096518002238}$

Moldova and Macedonia, although differing in many respects, share several critical structural factors that have impeded development, in general, and engendered an environment in which legislatures have not evolved into robust institutional supports for democratic governance. These two cases show the difficulty of consolidating democratic politics in newly established nation states that lack democratic traditions and are stranded on the periphery of the European Union (EU). The collective impact presence of Russian peacekeepers in the region effectively blocked Moldova's path to joining the EU. In Macedonia, a conflict with neighboring Greece over national identity caused a similar outcome. Politicians in Skopje and Chişinău, who recognize that there is no practical path to accession in the foreseeable future, are less subject to conditionality than their neighbors. Leadership groups in both countries have become adept at raising the possibility of alternative (i.e., Russian) political alignments as leverage against Western pressure.

Fourth, both Moldova and Macedonia have experienced levels of corruption that in recent years has risen to the level of "state capture" by networks of corrupt elites. In Moldova, corruption

Recently, political scientists observed that rising authoritarian and populist trends are threatening the progress of newly formed or reformed democracies around the world. In particular, the concern is that legislatures are ceding power to increasingly assertive executive bodies that work to supplant legislative processes with executive processes, which has marginalized pluralistic voices in developing democratic societies.

of these factors has been sufficiently detrimental to legislative performance as to overwhelm the importance of institutional arrangements per se. Although Macedonia may now be moving in a more positive direction as a consequence of its 2017 "colorful revolution," there is little evidence that either the Macedonian or the Moldovan legislature has had the ability to hold their executive branches in check.

What are the factors that underlie this outcome? First, neither country enjoyed a history of democratic self-governance on which it could fall back. Moldova had no modern history of independent national government. Its interwar experience of rule from Bucharest as part of Romania provided little useful guidance in developing sovereign democratic institutions. Incorporated into the USSR in 1940, Moldova was ruled by a series of Communist Party First Secretaries dispatched from Moscow. Similarly, Macedonia did not exist as a sovereign political entity in the modern era before its emergence from the Federal Republic of Yugoslavia in 1991.

Second, neither Macedonia nor Moldova experienced clear breaks with their Soviet-era politics. Rather, numerous former Soviet and Yugoslav political elites survived the regime transition to become the first generation of democratic leaders. In Macedonia, Kiro Gligorov-a reformist leader in the former Yugoslaviaretained his dominant role in Macedonia for a decade following independence. Elections held in 1992 were won by the former communists-renamed the Social Democratic Party of Macedonia (SDSM)-which then governed the country until 1998. In Moldova, a similar pattern of leadership continuity occurred. Mircea Snegur, last chairman of the Soviet-era Supreme Soviet, became the country's first president, followed in 1997 by former Communist Party First Secretary Petru Lucinschi. The leadership of nearly all major Moldovan parties was composed of Soviet-era elites. Thus, in both cases, post-communist state institutions were populated by personnel socialized in the habits of executive authority and authoritarian political parties.

Third, both Moldova and Macedonia have been stalled on the margins of the EU. In Moldova's case, the "frozen conflict" with Transnistria following its 1992 civil war and the continued has been endemic since the 1990 o but significantly worsened following removal of the Communist Party of the Republic of Moldova from power in 2009. Rather than representing the interests of the population, hypothetically pro-EU parties served the interests of powerful oligarchs who assumed control of broad swaths of the Moldovan economy. Whereas these top leaders overshadow Moldovan politics, a much broader network of clientelistic relationships and informal alliances permeates the entire top level of society, linking networks of interest across private and public sectors (Ciurea 2017). Similarly, in Macedonia, three charges of systemic corruption and abuse of office date back to the 1990s, when the SDSM allegedly used its political hegemony to enrich its leaders and supporters. Following the transition to the Internal Macedonian Revolutionary Organization-Democratic Party for Macedonian National Unity (VMRO-DPME) government in 2006, criticism focused on a growing network of corrupt relationships around party leader and Prime Minister Gruevski until his party's removal from power in 2017 (Cvetkovska and Holcova 2014). According to the report of an EU expert group convened to investigate the country's 2015 wiretapping scandal, government officials were complicit in corruption, extortion, nepotism, and cronyism (Recommendations of the Senior Experts' Group 2015, 6).

Thus, Moldova and Macedonia have both been stalled on the margins of the EU, where conditionality has been sufficient to restrain them from descending into full-blown authoritarianism but insufficient to restrain corruption that rises to the level of state capture. Clientelism and high levels of corruption played a key role in undermining legislative autonomy. Legislative candidates are placed on electoral lists and removed at the whim of top party leaders. On entering the legislature, they are obligated to party leaders who effectively control the legislative agenda. Oversight is fatally undermined by the power of party leaders, the lack of independence among Members of Parliaments (Bertelsmann Stiftung Transformation Index 2016, 10). As an Expert-Grup report concluded in Moldova, "[p] ower mostly lies not with public institutions, but with obscure special interests which have undermined and abused these institutions" (Expert-Grup 2011). . 


\section{REFEREN C ES}

Bertelsmann Stiftung Transformation Index. 2016. “TI 2016: Macedonia Country Report.” Gütersloh: Bertelsmann Stiftung.

Ciurea, Cornelie. 2017. "Political Risks in Moldova: A Barrier to International Investment?" In State Capture, Political Risks and International Business Cases from Black Sea Region Countries, eds. Johannes Leitner and Hannes Meissner, 120-37. London: Routledge.

Cvetkovska, Saska, and Pavla Holcova. 2014. "The Landlord Spy." Organized Crime and Corruption Reporting Project. May 8. Available at www.occrp.org/en/28ccwatch/cc-watch-indepth/2437-the-landlord-spy.

Expert-Grup. 2011. "Governance." Real Economy: Monthly Economic and Policy Review 21 (September). Available at www.expert-grup.org/library_upld/d387.pdf.

"Recommendations of the Senior Experts' Group on Systemic Rule of Law Issues Relating to the Communications Interception Revealed in Spring 2015." June 8, 2015. Brussels: The European Commission.

\section{THE RISE OF POWERFUL EXECUTIVES: COMPARING THE UKRAINIAN AND RUSSIAN LEGISLATURES}

Irina Khmelko, University of Tennessee, Chattanooga, USA

Oleksii Bruslyk, Yaroslav Mudryi National University, Ukraine

DOI: $10.1017 / S_{104909651800224 X}$

Although sharing in the pattern of losing power to powerful executives, post-communist legislatures in Russia and Ukraine differ significantly in institutional strengths, specifically in their ability to provide checks on executive power. Russia had a weakbut not powerless-parliament after the collapse of the Soviet Union (Cichock 2002, 85; Remington 2001). Research on modern Russia under Putin frequently refers to Russian society as "Putinism," which rests on a one-man rule (Fish 2017) in which a parliament is a "rubber stamp" to a president. Ukraine, however, is a rather puzzling case. The Ukrainian parliament is a strongly then methodically appointing "siloviki" (i.e., KGB and military staff) to governmental offices, which resulted in what is called the "neo-KGB state" (Economist 2007). His operatives from the ranks of the siloviki will follow orders, be loyal, and not hesitate to violate both the law and democratic practice, if necessary (Rivera and Rivera 2017).

This trend of militarization in Russia and its absence in Ukraine can be associated with how presidents in these two countries resolve political conflicts. The first standoff between the Russian president and parliament, in 1993, was resolved by tanks shooting at the parliament building in Moscow. Ukraine had political crises as well, but no Ukrainian president used military force against the parliament. For example, in 1993 , Ukrainian President Kravchuk resigned over conflict with Prime Minister Kuchma but did not apply military force to resolve the conflict. Instead, he signed the law "On Early Elections of the Verkhovna Rada of Ukraine and the President of Ukraine" and used the electoral process to resolve their partisan and ideological differences.

These two countries also differ in the degree to which election outcomes are manipulated. The lack of free and equal elections in Russia and the weakness of opposition parties are well documented in the literature (Ishiyama and Kennedy 2001; Korgunyuk, Ross, and Shpagin 2018; White 2017). In Ukraine, however, the most recent election brought to parliament a strong pro-presidential faction and many from majoritarian districts, what Ukrainians call "buckwheat" districts. They are named thus because something like a bag of buckwheat donated to an impoverished electorate can secure a vote in those districts. (The population reasons, "At least we can get this buckwheat now, because

\section{Ukraine's post-Soviet constitutional engineering resulted in a mixed governmental system in which power was distributed among the president, the prime minister, and a parliament. Russia established a strong presidential system in the early years of its post-Soviet history, with all power concentrated in the hands of a president.}

institutionalized legislature capable of performing independent policy roles; however, it struggles with performing basic functions, such as legislative oversight (Khmelko 2015). At the same time, the Ukrainian president, although not as strong as the Russian president, also is gaining strength at the expense of parliament.

What explains the different degrees of power that presidents were able to consolidate at the expense of legislatures in these two countries? First, countries differ in their choices of governmental systems, which allows for varying levels of power concentrated in the hands of a president. Ukraine's post-Soviet constitutional engineering resulted in a mixed governmental system in which power was distributed among the president, the prime minister, and a parliament. Russia established a strong presidential system in the early years of its post-Soviet history, with all power concentrated in the hands of a president.

A second factor is the Russian "militocracy," which is the militarization of Russian elites under Putin (Kryshtanovskaya and White 2003; Rivera and Rivera 2017). This began with Lieutenant Colonel Putin becoming the President of Russia and when elected, these politicians will not do anything else for us.") In addition, a closed-list proportional system hurts the party system in Ukraine. Parties there are led by a strong leader and the rest are usually faithful followers, known as "button pushers" on behalf of party leaders.

In conclusion, Ukraine has been more successful than Russia in providing sufficient checks on the executive to prevent the country from descending into a full autocracy. The combination of governmental system, election laws, and degree of militarization appears to be important in explaining the differences in outcomes between Russia and Ukraine. Our findings are in line with Linz's (1996a; 1996b) argument about the dangers of the presidential form of government for democratic consolidation. We add that a time lag between the collapse of the old soviet system and the development of a fully functional new system of government provides an opportunity for presidents to quickly deprive parliaments of important powers. The population indeed may obtain relief from the intense growing pains of any democratic transition, but the price in the long run is the failure of the democracy and a reversion to autocracy. The mixed governmental system divides 